\title{
Implementasi Outdoor Learning: Upaya Menanamkan Nilai-Nilai Keislaman Siswa SDIT Cahaya Rabbani Kepahiang
}

\author{
Fanny Rizki Fadilah, ${ }^{1}$ Idi Warsah, ${ }^{2}$ Deri Wanto ${ }^{3}$ \\ ${ }^{1,3}$ Fakultas Tarbiyah, ${ }^{2}$ Pascasarjana \\ Institut Agama Islam Negeri (IAIN) Curup, Bengkulu \\ ${ }^{1}$ fannyrizkif209@gmail.com. ${ }^{2}$ idiwarsah@iaincurup.ac.id. ${ }^{3}$ deriwanto56@gmail.com.
}

\begin{abstract}
The main objective of Islamic learning is the inculcation of religious values into each student. Such values must be embedded by teachers as early as possible, and this act is the hope of all students' parents at SDIT Rabbani Kepahiang. Thus, the teachers in this learningal institution make hard efforts with various innovations in implementing learning and learning to achieve the Islamic learning goals as well as the expectation of students' parents. One of the efforts made is the implementation of outdoor learning. This study sought to find the answers about the portrayal of the outdoor learning implementation by using a qualitative approach. The current study found out that the outdoor model was more oriented towards involving students in more actively studying the materials by deploying the surrounding natural media. Through this learning model, students could immediately make real observations so that the lessons given by the teachers could be directly practiced by students.

Tujuan utama pendidikan Islam adalah penanaman nilai-nilai agama pada setiap peserta didik. Nilai-nilai tersebut harus ditanamkan oleh guru sedini mungkin dan ini merupakan harapan seluruh wali siswa di SDIT Rabbani Kepahiang. Sehingga para guru di lembaga pendidikan tersebut berusaha keras dengan berbagai inovasi dalam melaksanakan pendidikan dan pembelajaran untuk mencapai tujuan pendidikan Islam dan sekaligus harapan wali siswa. Upaya yang dilakukan salah satunya adalah menerapkan pembelajaran outdoor. Studi ini ingin menemukan jawaban tentang gambaran pelaksanaan pembelajaran outdoor tersebut dengan menggunakan pendekatan kualitatif. Penelitian ini menemukan gambaran bahwa model outdoor lebih banyak melibatkan siswa untuk berperan aktif dalam menelaah materi dengan media alam sekitarnya. Melalui model pembelajaran tersebut siswa dapat langsung melihat dengan nyata, sehingga pelajaran yang diberi oleh guru dapat langsung dipraktekkan oleh peserta didik.
\end{abstract}

Keywords: Outdoor Learning, Islamic Values 


\section{A. Pendahuluan}

Secara teori hakikat dari sebuah pendidikan adalah usaha untuk mencerdaskan manusia dan untuk memanusiakan manusia. ${ }^{1}$ Upaya tersebut agar tercapai dengan baik, guru semestinya melakukan pembinaan dan pembelajaran kepada peserta didik sesuai dengan kebutuhan mereka masing-masing dan tidak serta merta sesuai keinginan guru. Sikap seperti ini secara implisit akan berdampak positif bagi kecerdasan anak bangsa, dan hal ini sangat diperlukan guna meningkatkan mutu bangsa secara menyeluruh.

Dengan demikian, penyelenggaraan pendidikan di Indonesia merupakan suatu sistem pendidikan nasional yang diatur secara sistematis. Pendidikan nasional berfungsi untuk mengembangkan kemampuan dan membentuk watak serta peradaban bangsa yang bermartabat dalam rangka mencerdaskan kehidupan bangsa, bertujuan untuk berkembangnya potensi peserta didik agar menjadi manusia yang beriman dan bertakwa kepada Tuhan yang Maha Esa, berakhlak mulia, berilmu, sehat, kreatif, cakap, mandiri dan menjadi warga negara yang demokratis serta bertanggung jawab. ${ }^{2}$

Hal tersebut juga dijelaskan dalam Undang-undang No. 20 Tahun 2003 tentang Sistem Pendidikan pasal 3 menegaskan bahwa: "pendidikan berfungsi mengembangkan kemampuan dan membentuk watak serta peradaban bangsa yang bermartabat dalam rangka mencerdaskan kehidupan bangsa, bertujuan untuk berkembangnya potensi peserta didik agar menjadi manusia yang beriman dan bertakwa kepada Tuhan yang Maha Esa, berakhlak mulia, sehat, berilmu, cakap, kreatif, mandiri, dan bertangggung jawab".

Dalam konteks mewujudkan cita-cita bangsa yang tertuang dalam undang-undang di atas, dalam sistem pendidikan yang baik. Pendidikan yang baik indikor utamanya adalah proses pembelajaran yang dilaksanakan oleh guru. Seperti telah disinggung di atas belajar dimaksud adalah belajar yang memberi makna bagi para peserta didik.

\footnotetext{
${ }^{1}$ Dedi Lazwardi, "Manajemen Kurikulum Sebagai Pengembangan Tujuan Pendidikan," $A l$ Idarah: Jurnal Kependidikan Islam 7, no. 1 (2017): 119-125.; Saifullah Idris and Z. A. Tabrani, "Realitas Konsep Pendidikan Humanisme Dalam Konteks Pendidikan Islam," Jurnal Edukasi: Jurnal Bimbingan Konseling 3, no. 1 (2017): 96-113.; Khusnul Khotimah, "Urgensi Kurikulum Gender Dalam Pendidikan," INSANIA: Jurnal Pemikiran Alternatif Kependidikan 13, no. 3 (2008): 420-533.; H. A. Yunus, "Telaah Aliran Pendidikan Progresivisme Dan Esensialisme Dalam Perspektif Filsafat Pendidikan," Jurnal Cakrawala Pendas 2, no. 1 (2016).

${ }^{2}$ Ondi Saondi and Aris Suherman, "Etika Profesi Keguruan,” (Bandung: Refika Aditama, 2010), 1
} 
| FANNY RIZKI FADILAH, DKK.| Implementasi Outdoor Learning: Upaya Menanamkan...

Jadi, belajar merupakan entitas yang tak pernah terpisah dari kehidupan manusia, dan merupakan salah satu kebutuhan hidup manusia yang paling penting dalam upaya mempertahankan kehidupan dan juga mengembangkan diri. Hal tersebut terjadi karena didorong kebutuhan dan tujuan yang ingin dicapai dalam suatu proses yang sistematis dan dinamis, konstruktif dan organik. Belajar juga merupakan bentuk pengalaman interaksi antara peserta didik dan lingkungannya. ${ }^{3}$ Belajar akan berlangsung dengan baik jika terjadi komunikasi yang baik antara guru dan pembelajar/peserta didik yang sering disebut dengan interaksi edukatif. Pada hakekatnya belajar merupakan proses komunikasi.

Jika ditinjau dari sudut pandang dunia pendidikan, belajar merupakan aktivitas pokok yang dilakukan. Artinya melalui proses pembelajaran peserta didik dapat memperoleh pemahaman tentang arti sesuatu konsep yang baru yang terlihat pada terjadinya perubahan tingkah laku, sikap dan keterampilan. ${ }^{4}$ Menurut Morgan (dalam Suprijono), "Learning is any relatively permanent change is behavior that is result of past experience." Inti dari paparan tersebut ialah menegaskan suatu pencapaian perubahan tingkah laku pada peserta didik secara permanen karena adanya proses pengalaman selama interaksi berlangsung.

Keberhasilan suatu proses pembelajaran di atas tidak terlepas dari peran serta guru. Guru dituntut untuk memiliki kompetensi professional yakni mampu melakukan inovasi dalam melaksanakan pembelajaran di kelas. ${ }^{6}$ Salah satu kiat guru yang inovatif antara lain: mereka mampu menerapkan model-model pembelajaran yang memudahkan mereka memberikan materi sehingga membuat suasana belajar menjadi hidup dan bermakna bagi peserta didik. Sampai pada saat evaluasi akan tergambar keberhasilan dari proses belajar tersebut sesuai dengan tujuan pendidikan itu sendiri.

\footnotetext{
${ }^{3}$ A. Pane and M. Darwis Dasopang, Belajar Dan Pembelajaran. FITRAH: Jurnal Kajian IlmuIlmu Keislaman, 3 (2), 333, 2017.

${ }^{4}$ I. Vandini, Peran Kepercayaan Diri Terhadap Prestasi Belajar Matematika Siswa. Formatif: Jurnal Ilmiah Pendidikan MIPA, 5 (3), 210-219, 2016.; Bambang Warsita, "Teori Belajar Robert M. Gagne Dan Implikasinya Pada Pentingnya Pusat Sumber Belajar,” Jurnal Teknodik 12, no. 1 (2018): 064078. Pustaka, 2013). 3

${ }^{5}$ Agus Suprijono, “Cooperative Learning Teori Dan Aplikasi PAIKEM (Pertama)," (Yogyakarta:

${ }^{6}$ Nurul Zuriah, Hari Sunaryo, and Nurbani Yusuf, "IbM Guru Dalam Pengembangan Bahan Ajar Kreatif Inovatif Berbasis Potensi Lokal,” Jurnal Dedikasi 13 (2016).
} 
Untuk mencapai tujuan pendidikan di atas, banyak hal yang harus dilakukan oleh guru sebagai garda terdepan pendidikan, salah satunya dengan melaksanakan pembelajaran yang tidak hanya di dalam kelas namun juga di luar kelas (Outdoor). ${ }^{7}$ Sebuah penelitian yang dilakukan oleh Nasutian menyimpulkan bahwa dalam kontek pendidikan jasmani pembelajar outdoor memberikan kontribusi positif terhadap kecerdasan sosial karena mereka langsung bersentuhan dengan alam sekitar. ${ }^{8}$ Sementara kecerdasan sosial menjadi keharusan untuk dipupuk pada setiap anak karena kecerdasan sosial merupakan indikator manusia beriman kepada Allah. ${ }^{9}$

Terkait dengan pembelajaran outdoor pada mata pelajaran lain, berkaca pada beberapa hasil penelitian terdahulu disimpulkan bahwa model ini efektif membantu siswa dalam memahami materi pembelajaran. Seperti hasil penelitian Estining Sejati, dkk. Menyimpulkan bahwa pembelajaran outdoor berpengaruh positif terhadap kemampuan menulis siswa pada mata pelajaran geografi. ${ }^{10}$ Begitu juga dengan hasil penelitian Budiyarti, dkk mengemukakan bahwa pembelajaran outdoor berpengaruh signifikan terhadap pemahaman siswa tentang sumber energy. ${ }^{11}$

Terkait dengan itu, yang tidak kalah penting menjadi pertimbangan dalam pembelaran adalah peserta didik. Hal ini menjadi urgen karena pendidikan sejak usia dini akan menjadi benteng tauhid bagi anak, yakni menanamkan pada anak untuk tidak menyekutukan Allah SWT. Model pembelajaran outdoor dipandang cocok oleh guru SDIT Cahaya Rabbani Kepahiang untuk menanamkan nilai-nilai keislaman pada peserta didik mereka. ${ }^{12}$

${ }^{7}$ Tedi Purbangkara and Nana Suryana Nasution, "Pengaruh Pembelajaran Outdoor Learning Pendidikan Jasmani Dalam Pembentukan Kecerdasan Emosional Pada Siswa MAN 3 Karawang," Jurnal Speed (Sport, Physical Learning, Empowerment) 2, no. 1 (2019): 68-76.

${ }^{8}$ Nana Suryana Nasution, "Pengembangan Kecerdasan Sosial Melalui Metode Pembelajaran Outdoor Learning Dalam Pendidikan Jasmani,” Judika (Jurnal Pendidikan Unsika) 6, no. 1 (2018): 7380.

${ }^{9}$ Idi Warsah, "Pendidikan Keimanan sebagai Basis Kecerdasan Sosial Peserta Didik: Telaah Psikologi Islami," Psikis: Jurnal Psikologi Islami 4, no. 1 (2018): 1-16.

${ }^{10}$ Andri Estining Sejati, Sumarmi Sumarmi, and I. Nyoman Ruja, "Pengaruh Metode Pembelajaran Outdoor Study Terhadap Kemampuan Menulis Karya Ilmiah Geografi SMA," Jurnal Pendidikan: Teori, Penelitian, Dan Pengembangan 1, no. 2 (2016): 80-86.

${ }^{11}$ Mei Rindang Budiarti, Peduk Rintayati, and Joko Daryanto, "Peningkatan Pemahaman Konsep Sumber Energi Melalui Metode Pembelajaran Outdoor Study," Didaktika Dwija Indria 2, no. 9 (2014).

${ }^{12}$ Hasil observasi pada tanggal 20 Maret 2020 
| FANNY RIZKI FADILAH, DKK.| Implementasi Outdoor Learning: Upaya Menanamkan...

Penanaman nilai keislamanan sejak dini akan membekali anak sejak dini juga untuk tidak tamak menghadapi beragam kekuasaan baik jabatan, harta, maupun kedudukan, semua yang diamanahkan hanyalah sarana atau alat untuk memahami kekuasaan dan kehendak Allah terhadap apa yang terjadi pada hamba-Nya. Anak-anak pada hakikatnya adalah generasi masa depan. Kepedulian yang besar terhadap mereka sekarang adalah bukti dalam memperbaiki, mendidik dan membangkitkan generasi mendatang. ${ }^{13}$

Dalam bentuk pendidikan bagi anak-anak yaitu pendidikan yang bergariskan prinsip mengenai masalah iman, akhlak, ibadah, sosial, dan ilmu pengetahuan. ${ }^{14}$ Penamanan ketauhidan adalah pondasi dalam setiap amal setiap orang. Ia merupakan pegangan pokok dan sangat menentukan kehidupan manusia. ${ }^{15}$ Kokohnya akidah seseorang dapat terlihat dari setiap amalannya. Sebaliknya rendahnya tauhid seorang muslim menunjukkan berkurangnya kadar akhlak, watak kepribadian dan kesiapan dalam menerima Islam sebagai pedoman dan pegangan hidupnya. ${ }^{16}$ Dalam proses belajar penanaman nilai-nilai keislaman ini tidak cukup dengan memaparkan teori dan konsep saja, namun harus dipraktekkan secara langsung di lapangan oleh guru dan guru termasuk model/contoh dari pembelajaran tersebut. ${ }^{17}$

Zakiah Darajat menyatakan bahwa pendidikan dan pengalaman yang dilalui oleh seorang anak, terutama pada masa pertumbuhan yang pertama (masa anak) dari umur 0 sampai dengan 12 tahun adalah penentu dalam perkembangan agama pada anak. Apabila seorang anak pada masa pertumbuhan itu tidak mendapatkan pendidikan agama dan tidak pula mempunyai pengalaman keagamaan, maka setelah nanti ia dewasa ia akan lebih cenderung kepada sikap negatif terhadap agama. ${ }^{18}$

Pendidikan Islam akan menjadi lebih istimewa karena memiliki kekuatan yang mendalam, berdasarkan keimanan, dan dalam rangka memperteguh aqidah. Sehingga

\footnotetext{
${ }^{13}$ Muhammad Athiyah Al-Abrasi, Beberapa Pemikiran Pendidikan Islam (Yogyakarta: Titian Illahi Press, 1996), .81.

${ }^{14}$ Zakiah Daradjat, Ilmu Pendidikan Islam (Jakarta: Bumi Aksara, 2008), 20.

${ }^{15}$ Constantin Constantin, "Urgensi Pendidikan Tauhid Dalam Keluarga," At-Talim 3 (2012).

${ }^{16}$ Daud Rasyid, Islam dalam Berbagai Dimensi (Jakarta: Gema Insani Press, 2000), 16.

${ }^{17}$ Daheri, Mirzon, and Idi Warsah. "Pendidikan Akhlak: Relasi Antara Sekolah dengan Keluarga.”, At-Turats: Jurnal Pemikiran Pendidikan Islam 13.7 (2019): 3-20. DOI: https://doi.org/10.24260/at-turats.v13i1.1285.g683

${ }^{18}$ Zakiyah Drajat, Ilmu Jiwa Agama (Jakarta: Bulan Bintang, 1989) 50.
} 
pendidikan Islam mempunyai peranan penting di dalam memajukan nilai-nilai kemanusiaan, mendidik emosi, etika, dan pendidikan intelektual. ${ }^{19}$

Konsep dalam pengembangan pendidikan yang islami yang ideal juga harus berlandaskan pragmatis learning. Konsep ini berpandangan bahwa setiap manusia merupakan individu yang memerlukan kelangsungan hidup, dengan cara berkembang dan berusaha bertahan baik fisik maupun mental dalam situasi apapun, dengan tetap memperhatikan kebutuhan keberlangsungan hidup tersebut. Pendidikan juga diharapkan dapat mengembangkan cultur learning. Hal ini secara tidak langsung menyadarkan menusia bahwa salah satu akar pendidikan adalah budaya dan dengannya manusia memiliki harga diri, berbudi luhur, percaya diri dan dapat berkembang dengan nilainilai ketuhanan. ${ }^{20}$

Nilai-nilai di atas akan berkembang dengan baik, tentu tidak cukup hanya mengandalkan pendidikan oleh orang tua, sekolah juga memberikan andil besar dalam mengembangkan nilai-nilai tersebut. Sekolah sebagai lembaga pendidikan formal dirancang oleh pemerintah maupun swasta tidak lain bertujuan agar terjadi interaksi yang baik dan seimbang antara guru dan peserta didik, sehingga guru sebagai orang dewasa dapat menjaga peserta didik sekaligus membimbing mereka agar menjadi individu yang bermanfaat di masa mendatang. ${ }^{21}$

Dalam memperoleh data tentang gambaran penerapan pembelajaran outdoor di SDIT Cahaya Rabbani Kabupaten Kepahiang yang akurat dan dapat dipertanggungjawabkan secara ilmiah, peneliti menggunakan pendekatan kualitatif dimaksudkan sebagai jenis penelitian yang temuan-temuannya tidak diperoleh melalui prosedur statistik atau bentuk hitungan lainnya. ${ }^{22}$ Penelitian kualitatif yaitu pengamatan, wawancara, atau penelaahan dokumen. Metode kualitatif ini digunakan karena beberapa pertimbangan. Pertama, menyesuaikan metode kualitatif lebih mudah apabila berhadapan dengan kenyataan jamak. Kedua, metode ini menyajikan secara langsung

\footnotetext{
${ }^{19}$ Al-Abrasi, Beberapa Pemikiran Pendidikan ...,51.

${ }^{20}$ Deri Wanto, "Kendala dan Perbaikan Pendidikan Islam yang Ideal," Conciencia 18, no. 1 (2018): 56-63.

${ }^{21}$ Akhmad Riandy Agusta, Punaji Setyosari, and Cholis Sa'dijah, "Implementasi Strategi Outdoor Learning Variasi Outbound Untuk Meningkatkan Kreativitas Dan Kerjasama Siswa Sekolah Dasar," Jurnal Pendidikan: Teori, Penelitian, Dan Pengembangan 3, no. 4 (2018): 453-459.

${ }^{22}$ Anselm Straus dan Juliet Corbin, Dasar-dasar Penelitian Kualitatif (Yogyakarta: Pustaka Pelajar, 2003), 4.
} 
| FANNY RIZKI FADILAH, DKK. | Implementasi Outdoor Learning: Upaya Menanamkan...

hakikat hubungan antara peneliti dan responden. Ketiga, metode ini lebih peka dan lebih dapat menyesuaikan diri dengan banyak penajaman pengaruh bersama terhadap polapola nilai yang dihadapi. ${ }^{23}$ Dalam penelitian ini peneliti menggunakan observasi dan wawancara. Teknik observasi digunakan untuk mengamati pelaksanaan pembelajaran outdoor yang dilakukan oleh guru SDIT Rabbani Kapahiang guna memperoleh data secara utuh tentang impelentasi pembelajaran dengan model tersebut. Sedangkan teknik wawancara digunakan untuk memperoleh infomasi secara verbal dari guru-guru SDIT Cayaha Rabbani bagaimana mereka menerapkan outdoor learning guna menanamkan nilai-nilai islami siswa.

Dalam memberikan penjelasan mengenai data yang diperoleh digunakan metode deskriptif kualitatif yaitu suatu metode penelitian yang berusaha mendetesiskan suatu gejala, peristiwa, kejadian yang bersifat sekarang. Selanjutnya analisis data yang dilakukan akan melalui beberapa tahapan: pertama, Data Reduction (Reduksi Data), Data Display (penyajian data), Conclusion Drawing/verification (kesimpulan) dan bila perlu dilakukan Triangulasi data.

\section{B. Pembahasan}

\section{Model Outdoor Learning}

Gunter et al mendefinisikan an instructional model is a step-by-step procedure that leads to specific learning outcomes. Joyce \& Weil mendefinisikan model pembelajaran sebagai kerangka konseptual yang digunakan sebagai pedoman dalam melakukan pembelajaran. Dengan demikian, model pembelajaran merupakan kerangka konseptual yang melukiskan prosedur yang sistematis dalam mengorganisasikan pengalaman belajar untuk mencapai tujuan belajar. $^{24}$ Jadi model pembelajaran

\footnotetext{
${ }^{23}$ Lexy J. Moleong, Metodologi Penelitian Kualitatif,(Bandung: Remaja Rosdakarya, 1989), 9.

${ }^{24}$ I. Made Tegeh, "Implementasi Model-Model Pembelajaran Inovatif untuk Pendidikan Vokasional," Proceeding Semnasvoktek 1 (2016): 10-10.; Golda Mair, "Penguasaan Model-Model Pembelajaran Meningkatkan Kompetensi Guru Bahasa Indonesia," Edukasi Kultura: Jurnal Bahasa, Sastra dan Budaya 1, no. 1 (n.d.).; Supriyadi Supriyadi, "Pembelajaran Bahasa dan Sastra Indonesia Yang Inovatif," FKIP E-Proceeding, 2017, 209-218.; Mendarissan Aritonang and Julaga Situmorang, "Pengaruh Model Pembelajaran Kooperatif Tsts-Nht dan Gaya Belajar terhadap Hasil Belajar Pengantar Bisnis," Jurnal Teknologi Pendidikan (JTP) 12, no. 1 (n.d.): 88-100.; R. Mursid, "Pengembangan Model Pembelajaran Penguatan Vocational Life Skills Mahasiswa Berwawasan Kewirausahaan Di Bidang Teknik Mesin," Jurnal Pendidikan Vokasi 7, no. 1 (2017): 110-122.; Siti Rochmiyati, "Mengembangkan Karakter Siswa dalam Pembelajaran Bahasa dengan Model Personal-Kooperatif," CARAKA 3, no. 2 (2017): 1-15..
} 
cenderung preskriptif, yang relatif sulit dibedakan dengan strategi pembelajaran. An instructional strategy is a method for delivering instruction that is intended to help students achieve a learning objective.

Membahas tentang pendekatan tentu tidak terlepas dari pembicaraan tentang proses pembelajaran karna ia merupakan hal yang sangat penting. Proses pembelajaran dibagi menjadi pembelajaran di dalam kelas (Indoor) dan pembelajaran luar kelas (Outdoor). Pembelajaran di dalam kelas lumrah ditemui, namun ada banyak hambatan yang menjadikan proses pembelajaran di dalam kelas (Indoor) menjadi tidak efektif, salah satu hambatannya adalah kejenuhan siswa saa jam belajar, pembelajaran di dalam ruangan yang menjadikan guru sebagai satu-satunya pusat perhatian. Seperti halnya metode pembelajaran konvensional.

Dalam kamus besar bahasa Indonesia konvensional berarti umum, seperti kebiasaan. Dalam kegiatan pembelajaran berpusat pada guru, guru mengajarkan tentang konsep-konsep bukan kompetensi, tujuannya yaitu siswa mengetahui sesuatu bukan untuk mampu melakukan sesuatu, dan pada proses pembelajarannya siswa lebih banyak mendengarkan saja. Sehingga pembelajaran kurang optimal karena guru membuat siswa pasif dalam pembelajaran.

Seperti yang terdapat dalam Warsah "Kalau selama ini pengajaran banyak dilakukan dengan hafalan dan drilling saja, maka kurikulum pada saat ini (apapun namanya) menekankan adanya kompetensi afektif dan psikomotor peserta didik. Tujuannya adalah agar peserta didik tidak hanya tahu tapi juga mampu melakukannya dalam tindakan nyata. Peserta didik diharapkan benar- benar merasakan bagaimana nilai-nilai yang selama ini diajarkan berguna dan membentuk perilaku" ${ }^{25}$ Salah satu jalan keluar untuk mengisi kejenuhan siswa dan untuk membangkitkan minat belajar siswa maka sesekali diadakan model pembelajaran di luar kelas (outdoor).

Kegiatan mengajar di luar kelas secara khusus merupakan kegiatan belajar mengajar guru dan murid, namun tidak dilakukan di dalam kelas, tetapi dilakukan di luar kelas atau alam terbuka, sebagai kegiatan pembelajaran, misalnya bermain di lingkungan sekolah, taman, perkampungan pertanian, nelayan, berkemah dan kegiatan

${ }^{25}$ Idi Warsah, "Kesadaran Multikultural sebagai Ranah Kurikulum Pendidikan," Ta'dib: Jurnal Pendidikan Islam 6, no. 2 (2017): 268-279. 
| FANNY RIZKI FADILAH, DKK.| Implementasi Outdoor Learning: Upaya Menanamkan...

yang bersifat petualangan, serta pengembangan aspek pengetahuan yang relevan. Metode mengajar di luar kelas juga dapat dipahami sebagai sebuah pendekatan pembelajaran yang menggunakan suasana di luar kelas sebagai situasi pembelajaran terhadap berbagai permainan, sebagai media transformasi konsep-konsep yang disampaikan dalam pembelajaran.

Mengajar di luar kelas bisa dipahami sebagai suatu kegiatan menyampaikan pelajaran di luar kelas, sehingga kegiatan atau aktivitas pembelajaran berlangsung di luar kelas atau di alam bebas. Sebagian orang menyebutnya dengan outing class yaitu suatu kegiatan yang melibatkan alam secara langsung untuk dijadikan sebagai sumber pembelajaran dengan sumber belajar yang sesungguhnya, yaitu alam dan masyarakat. Di sisi lain, mengajar di luar kelas merupakan upaya mengarahkan para siswa untuk melakukan aktivitas yang bisa membawa mereka pada perubahan perilaku terhadap lingkungan sekitar.

Komarudin menyatakan bahwa outdoor learning (atau biasa disebut outdoor learning) merupakan model belajar yang dilakukan di alam bebas di luar kelas bahkan bisa dilaksanakan di luar sekolah merupakan aktifitas luar sekolah. Dalam konteks pembelajaran di SDIT Cahaya Rabbani Kepahiang, Bengkulu, pembelajaran outdoor dilakukan oleh guru hanya di luar kelas saja seperti mengajak para siswa untuk melihat tumbuh-tumbuhan dan pemandangan alam di sekitar sekolah mereka. Selanjutnya guru menjelaskan kepada siswa tentang ke-Maha kuasaan Allah SWT yang menciptakan alam ini begitu indah dengan segala yang tumbuh dan hidup di dalamnya. ${ }^{26}$

Hal ini sejalan dengan terminologi pembelajaran outdoor tersebut seperti pendapat beberapa pakar bahwa proses pembelajaran bisa terjadi dimana saja, di dalam ataupun di luar kelas, bahkan di luar sekolah. Proses pembelajaran yang dilakukan di luar kelas atau bahkan di luar sekolah memiliki arti yang sangat penting bagi perkembangan siswa. $^{27}$

Karjawati berpendapat bahwa metode outdoor adalah metode dimana guru mengajak siswa belajar di luar kelas untuk melihat peristiwa langsung di lapangan dengan tujuan untuk mengakrabkan siswa dengan lingkungannya. Melalui metode

\footnotetext{
${ }^{26}$ Observasi dalam proses pembelajaran, 8 Januari 2020

${ }^{27}$ Husamah, Pembelajaran Luar Kelas OutdoorLearning (Jakarta: Prestasi Pustaka Publisher,
} 2013), 19. 
outdoor study lingkungan di luar sekolah dapat digunakan sebagai sumber belajar. Peran guru di sini adalah sebagai motivator, artinya guru sebagai pemandu agar siswa belajar secara aktif, kreatif, dan akrab dengan lingkungan. ${ }^{28}$

Adelia Vera dalam bukunya yang berjudul metode mengajar anak di luar kelas (outdoor study) mengungkapkan bahwa: “Outdoor learning itu sendiri yaitu suatu kegiatan menyampaikan pelajaran di luar kelas, sehinga kegiatan belajar mengajar berlangsung di luar kelas. Sebagian orang menyebutnya dengan outing class, yaitu suatu kegiatan yang melibatkan alam secara langsung untuk dijadikan sebagai sumber belajar. ، 29

Konsep inilah yang diterapkan oleh beberapa guru di SDIT Cahaya Rabbani Kepahiang dalam rangka menumbuhkan nilai-nilai islami siswa mereka, karena model pembelajaran ini berorientasi pada keaktifan siswa dengan pemanfaatan lingkungan sekitar secara langsung dan mengajak mereka untuk berpikir bahwa Allah itu ada dan maha kuasa atas alam yang mereka nikmati. Sehingga dalam pembelajaran ini guru lebih berperan sebagai fasilitator, pembimbing, dan mediator pembelajaran.

Proses pembelajaran di luar kelas dapat lebih membantu guru untuk memberikan penanaman nilai-nilai keagamaan terhadap siswanya. Karena melalui proses yang nyata langsung dapat dilihat oleh siswa. Pada Sekolah Dasar Islam Terpadu (SDIT) Cahaya Rabbani Kepahaiang, pembelajaran Outdoor dilakukan setiap hari misalnya pembiasaan shalat zuhur dan ashar secara berjamaah setiap hari sekolah. Lalu pembelajaran outdoor yang dilakukan setiap 1 semester 1 kali yaitu jika kelas 4, 5, dan 6 di lokasi pada lingkup provinsi, sedangkan kelas 1, 2, dan 3 dilakukan pada lingkup kabupaten saja.

Lalu pembelajaran yang dulu pernah dilakukan setiap 1 kali dalam satu minggu yaitu setiap hari sabtu, siswa kelas 5 melaksanakan kegiatan outdoor, misalnya hutan wisata Konak Kepahiang, di pagi hari Sabtu siswa di perintahkan untuk datang ke sekolah seperti biasa dan diperiksa seperti kerapian berpakaian, siswa yang belum memakai pakaian olahraga harus mengganti baju olahraga terlebih dahulu, membawa bekal dan juga memeriksa kesiapan siswa. Kemudian jam 08.00 barulah siswa di persilahkan berjalan kaki untuk menuju ke lokasi yaitu ke hutan wisata Konak

\footnotetext{
${ }^{28}$ Husamah.Pembeajaran Luar Kelas ... , 23.

${ }^{29}$ Adelia Vera, Metode Mengajar Anak Diluar Kelas (Outdoor Study) (Yogyakarta: DIVA Press, 2012), 15 .
} 
| FANNY RIZKI FADILAH, DKK.| Implementasi Outdoor Learning: Upaya Menanamkan...

Kepahiang. Hanya dengan berjalan kaki dengan alasan hutan wisata tersebut tidak jauh dari sekolah berkisar jarak 100 m. Sesampainya Disana guru mulai memasuki materi tentang hidup sederhana dan ikhlas.

Ketika ditanya tentang alasan apa yang mendorong guru menggukan pembelajaran outdoor, menurut Guru kelas 5 SDIT Cayaha Rabbani Kepaiang, meodel ini dapat mengurangi kejenehuan siswa yang telah belajar di dalam kelas beberapa jam. Siswa menjadi rileks dan termotivasi menerima materi. Mereka menganggap bahwa mereka belajar sambil bermain. Tentu kondisi psikis siswa demikian akan sangat mempengaruhi daya tangkap siswa dalam menerima dan memahami konsep yang dipelajari. Bila dalam suatu proses pembelajaran siswa merasa senang, tidak jenuh dan bosan, maka daya tangkap siswa dalam menerima dan memahami konsep yang dipelajari akan baik sehingga secara langsung dapat mempengaruhi hasil belajar peserta didik itu sendiri. ${ }^{30}$

Dengan kata lain harapan guru menerapkan model pembelajaran ini agar siswasiswi di SDIT Cahaya Rabbani Kepahiang tidak jenuh saat belajar dan untuk memudahkan siswa dan siswi dalam memahami proses pembelajaran. Karena proses yang dilakukan adalah proses yang nyata langsung dilihat dan dipraktekkan sendiri oleh siswa siswi SDIT Cahaya Rabbani.

Argumentasi narasumber di atas sejalan dengan tujuan pembelajaran outdoor perspektif Sement Priest menyatakan pendidikan luar kelas memiliki tujuan agar para siswa dapat beradaptasi dengan lingkungan dan alam sekitar dan mengetahui pentingnya keterampilan hidup dan pengalaman hidup di lingkungan dan alam sekitar, dan memiliki apresiasi terhadap lingkungan dan alam sekitar. ${ }^{31}$

Sementara menurut Adelia Vera tujuan pendidikan yang ingin dicapai melalui aktivitas belajar di luar kelas (outdoor) sekolah ialah sebagai berikut: 1) Mengarahkan peserta didik untuk mengembangkan bakat dan kreatifitas mereka dengan seluasluasnya; 2) menyediakan latar (setting) yang berarti bagi pembentukan sikap dan mental siswa; 3) Meningkatkan kesadaran, apresiasi, dan pemahaman peserta didik terhadap lingkungan; 4) Membantu mengembangkan segala potensi setiap siswa agar menjadi

\footnotetext{
${ }^{30}$ Wawancara dengan guru kelas 5 SDIT Cahaya Rabbani Kepahiang, 9 Januari 2020

${ }^{31}$ Husamah.Pembelajaran Luar Kelas ...., 21.
} 
manusia sempurna, yaitu memiliki perkembangan jiwa, raga, dan spirit yang kuat; 5) Memberikan konteks dalam proses pengenalan berkehidupan sosial dalam tataran praktik; 6) Menunjang keterampilan dan ketertarikan peserta didik; 7) Menciptakan kesadaran dan pemahaman peserta didik cara menghargai alam dan lingkungan, serta hidup berdampingan di tengah perbedaan suku, ideologi, agama, politik, ras, bahasa, dan lain sebagainya; 8) Mengenalkan berbagai kegiatan di luar kelas yang dapat membuat pembelajaran lebih kreatif; 9) Memberikan kesempatan yang unik bagi peserta didik untuk perubahan perilaku; 10) Memberikan kontribusi penting dalam rangka membantu mengembangkan hubungan guru dan siswa; 11) Menyediakan waktu seluasluasnya bagi peserta didik untuk belajar dari pengalaman langsung melalui implementasi bebas kurikulum sekolah di berbagai area; 12) Memanfaatkan sumbersumber yang berasal dari lingkungan; 13) Agar peserta didik dapat memahami secara optimal seluruh matapelajaran. ${ }^{32}$

\section{Implementasi Pembelajaran Outdoor dalam Menanamkan Nilai-nilai Agama Islam Siswa SDIT Cahaya Rabbani Kepahiang}

Thoha menjelaskan bahwa nilai merupakan sifat yang melekat pada sesuatu (sistem kepercayaan), yang telah berhubungan dengan subjek yang memberi arti (manusia yang meyakini). Jadi, nilai adalah sesuatu yang bermanfaat dan berguna bagi manusia sebagai acuan tingkah laku. ${ }^{33}$ Bagus menyebutkan nilai sebagai harkat kualitas suatu hal yang dianggap istimewa dan yang disukai, karena mempunyai nilai tinggi. ${ }^{34}$ Berbeda dengan kedua pendapat di atas, Peter Salim dan Yeni Salim menyebutkan bahwa nilai suatu konsep abstrak yang terdapat dalam diri manusia mengenai sesuatu yang dianggap baik dan benar dalam hal-hal yang dianggap benar dan salah. ${ }^{35}$ Drajat menyebutkan nilai adalah suatu perangkat keyakinan atau perasaan yang diyakini sebagai identitas yang memberikan ciri khusus pada pemikiran, perasaan, kriteria maupun perilaku. ${ }^{36}$

\footnotetext{
${ }^{32}$ Adelia Vera,Metode Mengajar Anak ...,.21-25.

${ }^{33}$ M. Chabib Thoha, Kapita Selekta Pendidikan Islam (Yogyakarta: Pustaka Pelajar, 1996), 61.

${ }^{34}$ Lorens Bagus, Kamus Filsafat, (Jakarta: Gramedia Pustaka Utama, 1996), 173.

${ }^{35}$ Peter Salim dan Yeni Salim, Kamus Besar Bahasa Indonesia Kontemporer (Jakarta: Modern English Press, 1996), 1034.

${ }^{36}$ Zakiyah Daradjat, Ilmu Jiwa Agama (Jakarta: Bulan Bintang, 1996), 59.
} 
| FANNY RIZKI FADILAH, DKK.| Implementasi Outdoor Learning: Upaya Menanamkan...

Agama berasal dari kata Sankskrit, ada yang berpendapat bahwa kata itu terdiri dari dua kata, a berarti tidak dan gam berarti pergi jadi agama artinya tidak pergi, tetap ditempat, diwarisi turun menurun. Agama memang mempunyai sifat yang demikian. Pendapat lain mengatakan bahwa agama berarti teks atau kitab suci. Selanjutnya dikatakan bahwa gam berarti tuntunan. Agama juga mempunyai tuntunan, yaitu kitab suci. Istilah agama dalam bahasa asing bermacam-macam, antara lain religion dan aldhin. ${ }^{37}$ Kata al-dhin dalam bahasa arab terdiri atas huruf dal, ya dan nun. Dari hurufhuruf ini bisa dibaca dengan dain yang berarti utang dan dengan din yang mengandung arti agama dan hari kiamat. ${ }^{38}$

Agama merupakan risalah yang disampaikan Tuhan kepada nabi-Nya sebagai pemberi peringatan serta pemberi petunjuk dalam hukum- hukum sempurna untuk dipergunakan manusia dalam menyelenggarakan tata hidup yang nyata. Mengatur tanggung jawab manusia kepada Allah.masyarakat dan alam sekitarnya. ${ }^{39}$

Saefuddin mengatakan bahwa agama merupakan kebutuhan paling esensial manusia yang bersifat universal. Tetapi makna paling hakiki agama adalah kesadaran spiritual, yaitu manusia selalu mengharap belas kasih-Nya, bimbingan tangan-Nya, serta belaian-Nya, yang secara ontologis tidak bisa dipungkiri, walaupun oleh manusia yang paling komunis sekalipun. ${ }^{40}$ Agama merupakan faktor terpenting dalam hidup dan kehidupan manusia. Karena, agama mampu memberikan makna, arti, tujuan hidup dan kehidupan manusia itu sendiri. ${ }^{41}$

Berpijak pada beberapa pengertian di atas dapat dipahani bahwa nilai-nilai agama Islam adalah seperangkat ajaran nilai-nilai luhur yang ditransfer dan diadopsi ke dalam diri untuk mengetahui cara menjalankan kehidupan sehari-hari sesuai dengan ajaran-ajaran Islam dalam membentuk kepribadian yang utuh. Seberapa banyak dan seberapa jauh nilai-nilai agama Islam bisa mempengaruhi dan membentuk suatu karakter seseorang sangat tergantung dari seberapa nilai-nilai agama yang

\footnotetext{
${ }^{37}$ Harun Nasution, Islam DItinjau Dari Berbagai Aspeknya (Jakarta: UI Press, 1979), 9.

${ }^{38}$ Quraisy Shihab, Mahkota Tuntunan Illahi (Jakarta: Untagama, 1986), 35.

${ }^{39}$ Muhammaddin Muhammaddin, "Kebutuhan Manusia Terhadap Agama," Jurnal Ilmu Agama: Mengkaji Doktrin, Pemikiran, Dan Fenomena Agama 14, no. 1 (2013): 99-114.

${ }^{40}$ A.M. Saefuddin, dkk. Desekularisasi Pemikiran Landasan Islamisasi, (Bandung: Mizan, 1987), 47.

${ }^{41}$ Ahmad Yani, "Pendidikan Agama Pada Anak Oleh Orang Tua: Tinjauan Psikologi Islam," Jurnal Ilmu Agama: Mengkaji Doktrin, Pemikiran, Dan Fenomena Agama 14, no. 1 (2013): 33-44.
} 
terinternalisasi pada dirinya. Semakin dalam terinternalisasinya nilai-nilai agama Islam pada diri seseorang, maka kepribadian dan sikap religiusnya akan muncul dan terbentuk.

Nilai agama berhubungan antara manusia dengan Tuhan, kaitannya adalah dengan pelaksanaan perintah dan larangannya. Nilaiagama diwujudkan dalam bentuk amal perbuatan yang dicintai oleh Allah SWT dan membawa kebaikan di dunia maupun di akhirat. Bila seseorang melanggar norma/kaidah agama, ia akan mendapatkan sanksi dari Allah SWT. Nilai-nilai agama yang terdapat dalam perilaku manusia, seiring dengan berjalannya waktu dapat menjadi norma-norma sosial yang mengikat suatu masyarakat. ${ }^{42}$ Nilai-nilai agama dalam penelitian di SDIT Cahya Rabbani adalah nilai agama yang terkandung pada setiap materi keislaman yang diajarkan di sekolah tersebut.

Jadi materi akidah akhlak, fikih, al-Qur'an dan materi keislaman yang lain dijelaskan secara kontekstual dengan cara mengaitkan alam sekitar dengan muatan materi tersebut, misalnya pada materi ketauhidan mereka menjelaskan bahwa alam ini ada tidak semata-mata langsung ada tetapi ada yang mencipkatakannya, pada materi akhlak mereka diajarkan bagaimana tata cara bersikap terdapat alam dan pada materi fikih mereka ditekankan untuk menjaga kebersihan lingkungan agar tetap terjaga kelestariannya, sementara pada materi al-Quran mereka diajarkan bahwa al-Qur'an adalah ayah-ayat Qauliyah sementara alam sekitar adalah ayat-ayat Kauniyah (tandatanda bahwa Allah itu ada). ${ }^{43}$

Tentu di dalam lingkungan sekolah ada banyak hal yang dapat dijadikan sebagai suatu pilihan oleh orang tua siswa untuk menitipkan anak mereka menimba ilmu di sekolah tersebut. Misalnya, Kurikulum apa yang digunakan, para pendidik yang bagaimana, model-model pembelajaran yang seperti apa, bagaimana hasil lulusan dari sekolah tersebut, dan masih banyak lagi sebagainya.

Sekolah Dasar Islam Terpadu Cahaya Rabbani merupakan suatu lembaga pendidikan yang sangat menjunjung tinggi penanaman nilai-nilai Keislaman pada siswa-siswanya. Hal ini juga dapat dibuktikan dengan banyaknya proses pembelajaran

\footnotetext{
${ }^{42}$ Amir Syamsudin, "Pengembangan Nilai-Nilai Agama Dan Moral Pada Anak Usia Dini," Jurnal Pendidikan Anak 1, no. 2 (2012).

${ }^{43}$ Wawancara kepada ibu kepala Sekolah SDIT Cahaya Rabbani Kepahiang, 10 Januari 2020
} 
| FANNY RIZKI FADILAH, DKK.| Implementasi Outdoor Learning: Upaya Menanamkan...

yang dilakukan pada SDIT ini guna lebih memudahkan atau membiasakan para siswa nya untuk mendapatkan ilmu-ilmu agama.

Hal ini membuat hati orang tua terbuka untuk mendaftarkan anak mereka SDIT Cahaya Rabbani, ini dibuktikan dengan banyaknya calon peserta didik yang terdaftar untuk mengikuti tes masuk pada tahun ini. sayangnya calon peserta didik yang akan masuk sudah melebihi kapastitas, maka calon peserta didik yang telah mendaftar akan menerima tes ujian masuk. setelah tes berlangsung maka peserta didik yang lulus akan langsung bersekolah di SDIT Cahaya Robbani ini. ${ }^{44}$

Ketika ditanya tentang bagaimana guru menerapkan model pembelajaran outdoor ini pada siswa kelas 5 SDIT Cahaya Rabbani. Beberapa tahapan yang dilakukan oleh guru berdasarkan hasil wawancara dan observasi langsung di lapangan penelitian diperoleh gambaran bahwa, langkah-langkah yang dilakukan oleh guru tersebut adalah antara lain adalah: penguasaan bahan ajar, mempersiapkan pertanyaan setelah menjelaskan materi, mempersiapkan media, melakukan suvey ke lapangan agar dipastikan bahwa lingkungan aman dari berbagai hal yang akan membahayakan siswa.

Setelah langkah awal telah dipersiapkan, kemudian guru mengajak siswa keluar kelas dan membagi kelompok, memberikan panduan pembelajaran sekaligus menjelaskan materi keisalaman yang akan dibahas selanjutnya menjelaskan kepada meraka tentang kerja kelompok masing-masing, sehingga siswa diminta untuk membuat simpulan dalam lembar kerja sebagai bahan diskusi antar kelompok. Dalam hal memberikan tugas guru tidak lupa memberikan motivasi kepada siswa, agar siswa dapat mengambil kesimpulan dari pembelajaran yang telah berlangsung baik inti dari materi, hambatan dan kesulitan yang mereka temui dalam pembelajaran tersebut. Guru memberikan kesimpulan bersama siswa. ${ }^{45}$

Sekilas pembelajaran ini efektif diterapkan pada pembelajaran keagamaan, namun menurut guru kelas 5 SDIT Rabbani. Pembelajaran oudoor memiliki beberapa kelemahan: kurangnya konsentrasi pada siswa, sulit mengkodisikan siswa apalagi jika tidak dibuat kelompok dan tidak ada penanggungjawab kelompok, memerlukan banyak waktu, guru lebih sibuk mengontrol siswa dari pada memberikan materi. Namun

\footnotetext{
${ }^{44}$ Wawancara kepada Kepala Sekolah di SDIT Cahaya Rabbani Kepahiang. 10 Januari 2020

${ }^{45}$ Observasi tanggal 9 Januari 2020
} 
demikian, menurut guru kelas 5 tersebut, kelemahan tersebut dapat dikondisikan dengan tidak mengajak siswa terlalu jauh dari lingkungan sekolah agar siswa dapat dikondisikan dengan baik. ${ }^{46}$

\section{Kesimpulan}

Penerapan pembelajaran outdoor di SDIT Cahaya Rabbani cukup efektif untuk menanankan nilai-nilai keislaman siswa. Penerapan pembelajaran model tersebut lebih banyak melibatkan siswa untuk berperan aktif dalam menelaah materi pembelajaran dengan media alam sekitarnya. Pembelajaran outdoor dapat mengurangi rasa jenuh siswa belajar dalam ruangan kelas. Melalui model pembelajaran tersebut siswa dapat langsung melihat dengan nyata, sehingga pelajaran yang diberi oleh guru dapat langsung dipraktekkan oleh siswa.

\footnotetext{
${ }^{46}$ Wawancara tanggal 9 Januari 2020
} 
| FANNY RIZKI FADILAH, DKK. | Implementasi Outdoor Learning: Upaya Menanamkan...

\section{Daftar Pustaka}

Abrasi Al-, Muhammad Athiyah Beberapa Pemikiran Pendidikan Islam (Yogyakarta: Titian Illahi Press, 1996)

Agusta, Akhmad Riandy, Punaji Setyosari, and Cholis Sa'dijah. "Implementasi Strategi Outdoor Learning Variasi Outbound Untuk Meningkatkan Kreativitas Dan Kerjasama Siswa Sekolah Dasar." Jurnal Pendidikan: Teori, Penelitian, Dan Pengembangan 3, no. 4 (2018): 453-459.

Aritonang, Mendarissan, and Julaga Situmorang. "PENGARUH MODEL PEMBELAJARAN KOOPERATIF TSTS-NHT DAN GAYA BELAJAR TERHADAP HASIL BELAJAR PENGANTAR BISNIS.” Jurnal Teknologi Pendidikan (JTP) 12, no. 1 (n.d.): 88-100.

Bagus, Lorens, Kamus Filsafat (Jakarta: Gramedia Pustaka Utama, 1996)

Budiarti, Mei Rindang, Peduk Rintayati, and Joko Daryanto. "Peningkatan Pemahaman Konsep Sumber Energi Melalui Metode Pembelajaran Outdoor Study.” Didaktika Dwija Indria 2, no. 9 (2014).

Constantin, Constantin. "Urgensi Pendidikan Tauhid Dalam Keluarga.” At-Talim 3 (2012).

Daheri, Mirzon, and Idi Warsah. "PENDIDIKAN AKHLAK: RELASI ANTARA SEKOLAH DENGAN KELUARGA.", At-Turats: Jurnal Pemikiran Pendidikan Islam 13.7 (2019): 3-20. DOI: https://doi.org/10.24260/at-turats.v13i1.1285.g683

Daradjat, Zakiyah, Ilmu Jiwa Agama (Jakarta: Bulan Bintang, 1996)

Husamah, Pembelajaran Luar Kelas OutdoorLearning (Jakarta: Prestasi Pustaka Publisher, 2013),

Khotimah, Khusnul. "Urgensi Kurikulum Gender Dalam Pendidikan." INSANIA: Jurnal Pemikiran Alternatif Kependidikan 13, no. 3 (2008): 420-533.

Lazwardi, Dedi. "Manajemen Kurikulum Sebagai Pengembangan Tujuan Pendidikan." AlIdarah: Jurnal Kependidikan Islam 7, no. 1 (2017): 119-125.

Mair, Golda. "PENGUASAAN MODEL-MODEL PEMBELAJARAN MENINGKATKAN KOMPETENSI GURU BAHASA INDONESIA.” EDUKASI KULTURA: JURNAL BAHASA, SASTRA DAN BUDAYA 1, no. 1 (n.d.).

Moleong, Lexy J. Metodologi Penelitian Kualitatif (Bandung: Remaja Rosdakarya, 1989)

Muhammaddin, Muhammaddin. "Kebutuhan Manusia Terhadap Agama." Jurnal Ilmu Agama: Mengkaji Doktrin, Pemikiran, Dan Fenomena Agama 14, no. 1 (2013): 99-114.

Mursid, R. "Pengembangan Model Pembelajaran Penguatan Vocational Life Skills Mahasiswa Berwawasan Kewirausahaan Di Bidang Teknik Mesin.” Jurnal Pendidikan Vokasi 7, no. 1 (2017): 110-122.

Nasution, Harun, Islam DItinjau Dari Berbagai Aspeknya (Jakarta: UI Press, 1979)

Nasution, Nana Suryana. "PENGEMBANGAN KECERDASAN SOSIAL MELALUI METODE PEMBELAJARAN OUTDOOR LEARNING DALAM PENDIDIKAN JASMANI." JUDIKA (JURNAL PENDIDIKAN UNSIKA) 6, no. 1 (2018): 73-80.

Pane, A., and M. Darwis Dasopang. Belajar Dan Pembelajaran. FITRAH: Jurnal Kajian IlmuIlmu Keislaman, 3 (2), 333, 2017.

Purbangkara, Tedi, and Nana Suryana Nasution. "Pengaruh Pembelajaran Outdoor Learning Pendidikan Jasmani Dalam Pembentukan Kecerdasan Emosional Pada Siswa MAN 3 Karawang.” Jurnal Speed (Sport, Physical Learning, Empowerment) 2, no. 1 (2019): $68-76$. 
Rasyid, Daud, Islam dalam Berbagai Dimensi (Jakarta: Gema Insani Press, 2000)

Rochmiyati, Siti. "MENGEMBANGKAN KARAKTER SISWA DALAM PEMBELAJARAN BAHASA DENGAN MODEL PERSONAL-KOOPERATIF." CARAKA 3, no. 2 (2017): 1-15.

Salim, Peter dan Salim,Yeni, Kamus Besar Bahasa Indonesia Kontemporer (Jakarta: Modern English Press, 1996)

Saondi, Ondi, and Aris Suherman. "Etika Profesi Keguruan." (Bandung: PT Refika Aditama, 2010).

Sejati, Andri Estining, Sumarmi Sumarmi, and I. Nyoman Ruja. "Pengaruh Metode Pembelajaran Outdoor Study Terhadap Kemampuan Menulis Karya Ilmiah Geografi SMA.” Jurnal Pendidikan: Teori, Penelitian, Dan Pengembangan 1, no. 2 (2016): 8086.

Shihab, M. Quraisy, Mahkota Tuntunan Illahi (Jakarta: Untagama, 1986)

Suprijono, Agus. "Cooperative Learning Teori Dan Aplikasi PAIKEM (Pertama)." (Yogyakarta: Pustaka, 2013).

Supriyadi, Supriyadi. "PEMBELAJARAN BAHASA DAN SASTRA INDONESIA YANG INOVATIF." FKIP E-PROCEEDING, 2017, 209-218.

Saefuddin, A.M. dkk. Desekularisasi Pemikiran Landasan Islamisasi (Bandung: Mizan, 1987)

Straus, Anselm dan Corbin, Juliet, Dasar-dasar Penelitian Kualitatif, (Yogyakarta: Pustaka Pelajar, 2003)

Syamsudin, Amir. "Pengembangan Nilai-Nilai Agama Dan Moral Pada Anak Usia Dini." Jurnal Pendidikan Anak 1, no. 2 (2012).

Tegeh, I. Made. "IMPLEMENTASI MODEL-MODEL PEMBELAJARAN INOVATIF UNTUK PENDIDIKAN VOKASIONAL.” Proceeding Semnasvoktek 1 (2016): 10-10.

Thoha, M. Chabib. Kapita Selekta Pendidikan Islam (Yogyakarta: Pustaka Pelajar, 1996)

Vandini, I. Peran Kepercayaan Diri Terhadap Prestasi Belajar Matematika Siswa. Formatif: Jurnal Ilmiah Pendidikan MIPA, 5 (3), 210-219, 2016.

Vera, Adelia, Metode Mengajar Anak Diluar Kelas (Outdoor Study) (Yogyakarta: DIVA Press, 2012)

Wanto, Deri. "KENDALA DAN PERBAIKAN PENDIDIKAN ISLAM YANG IDEAL." Conciencia 18, no. 1 (2018): 56-63.

Warsah, Idi. "Kesadaran Multikultural Sebagai Ranah Kurikulum Pendidikan." Ta'dib: Jurnal Pendidikan Islam 6, no. 2 (2017): 268-279.

- "PENDIDIKAN KEIMANAN SEBAGAI BASIS KECERDASAN SOSIAL PESERTA DIDIK: TelAAH PSIKOLOGI ISLAMI.” Psikis: Jurnal Psikologi Islami 4, no. 1 (2018): 1-16.

Warsita, Bambang. "Teori Belajar Robert M. Gagne Dan Implikasinya Pada Pentingnya Pusat Sumber Belajar." Jurnal Teknodik 12, no. 1 (2018): 064-078.

Yani, Ahmad. "Pendidikan Agama Pada Anak Oleh Orang Tua: Tinjauan Psikologi Islam." Jurnal Ilmu Agama: Mengkaji Doktrin, Pemikiran, Dan Fenomena Agama 14, no. 1 (2013): 33-44.

Yunus, H. A. "Telaah Aliran Pendidikan Progresivisme Dan Esensialisme Dalam Perspektif Filsafat Pendidikan.” Jurnal Cakrawala Pendas 2, no. 1 (2016).

Zuriah, Nurul, Hari Sunaryo, and Nurbani Yusuf. "IbM Guru Dalam Pengembangan Bahan Ajar Kreatif Inovatif Berbasis Potensi Lokal.” Jurnal Dedikasi 13 (2016). 